patients, to-day the annual number exceeds 150,000 . These figures speak for themselves and are a matter for congratulation for all concerned.

\title{
Arrangements during the War: Preliminary Notice
}

The management of the British Journal of Ophthalmology hopes to be able to publish 48 page numbers till the end of this year in order to complete the XXIIIrd volume. It has been decided to discontinue the section on contemporary ophthalmic literature and drastically to curtail the abstract section.

We hope to give a note on future policy in the December issue.

\section{ABSTRACTS}

\section{I.-MISCELLANEOUS}

(1) Lyons, Maxwell F. (Cairo).-The biomicroscopy of spring catarrh. Twelfth Annual Report of the Memorial Ophthalmic Laboratory, Egypt. Schindler's Press, Cairo.

(1) An abstract of Lyons previous work on spring catarrh was given in Vol. XXII, No. 9, p. 563. He stated that the lesions are not due to a proliferation of pre existing connective tissue but to an invasion of the normal conjunctiva by new fibrinous material and wandering cells, originating from the capillaries of the conjunctiva; that there must be an intangible and indefinite abnormality of the capillaries, and that the lesions are merely local manifestations of a general bodily departure from the normal. The process is the same whether the disease attacks the palpebral or the bulbar conjunctiva, and the form each lesion talies depends on the structural characteristics of the site involved and the degree of capillary leakage.

This disease is always bilateral and usually symmetrical. It may begin in any part of the vascularized subepithelial tissues of the lid or globe, either from the vessels normally present in the episcleral tissue or from new vessels such as those of trachomatous pannus. This may be one of the chief reasons for the frequency and severity of spring catarrh in trachoma-infested countries.

If the conjunctiva is wiped with a swab and immediately examined under magnification, tiny droplets like dew are seen to exude through the epithelium. They grow in size and coalesce to form a film over the tarsal conjunctiva. As soon as one film is removed another 
forms since the conjunctiva is so firmly adherent to the tarsus that it cannot expand rapidly enough to accommodate all the fibrinous material which is constantly exuding from the capillaries. This exudate is forced out between the epithelial cells to form the membrane, some of it however, balloons up the epithelium to form broad papillae, which. from mutual pressure become polygonal in shape. New vessels grow into each papilla appearing beneath the epithelium as minute branching twigs. The palpebral form of the disease may absorb between active periods as does the bulbar form, the conjunctiva becoming smooth and flat. Greyish-white lines represent the inter-pupillary attachment of the epithelium to the tarsus. When organization of the exudate has taken place a fine reticulum of intersecting cicatricial fibres results. This can usually be distinguished from the cicatrization of trachoma by its greater regularity.

The lesion of spring catarrh in its simplest form occurs in the interpalpebral zone of the bulbar conjunctiva. Owing to the looseness of the conjunctiva here and the lack of support from the lids little resistance is offered to leakage from the capillaries, which according to the author is the important factor of the disease. The earliest signs are a dilatation of the superficial vessels with slight chemosis. As the exudation increases a mass is formed, which may attain a considerable size within a couple of months; and this may fade away rapidly during the winter months.

When the leakage is from the zones of vascular loops, and endcapillary loops, a narrow gelatinous ring develops, round the cornea.

When the new vessels of trachomatous pannus begin to leak an extension of the pathological change to the cornea must occur. An irregular ring of confluent nodules develops around the limbus, causing an apparent diminution of the corneal diameter.

All forms of spring catarrh are characterized by an increase in the pigmentation of the epithelium, chiefly around the limbus.

The author states that primary involvement of the cornea by spring catarrh occasionally occurs when trachomatous pannus is present.

In the early stage of the palpebral form of spring catarrh one can detect the formation of the typical membrane which, being composed of fibrin, and eosinophils is pathognomonic of the disease.

The first detailed account of spring catarrh in Egypt was given by Meyerhof (Klin. Monatsbl. f. Augenheilk., June, 1912, and Bull. Soc. d'Ophtal. d'Egypte, 1912) in which he pointed out that the first recognition of the disease was by MacCallan who reported this in The Ophthalmoscope, Nov.-Dec., 1908, and Ophthalmic Record, Dec., 1910. From this resulted the designation of a special group of cases, trachoma complicated by spring catarrh, " trachoma stage II b" in MacCallan's classification of trachoma.

Meyerhof showed that there was a hereditary factor in spring 
catarrh, and he also remarked on its occasional unilateral occurrence. The latter phenomenon had previously been noted by Axenfeld (Bull. Soc. Française d'Ophtal., 1907).

\section{A. F. MacCallan.}

(2) Kukán, F. (Pécs):-Closure of the angle of the anterior chamber by negative pressure. (Verschliessung des Kammerwinkels durch negativen Druck). Klin. Monatsbl. $f$. Augenheilk., Vol. C, p. 68, 1938.

(2) Kukan describes some interesting experiments on the effect of negative external pressure on intra-ocular tension. The application of a pressure cup fitting round the limbus, with a negative pressure of $150 \mathrm{~mm}$. exerted for three minutes, causes little alteration in the intra-ocular pressure, whereas a wider cup which extends on to the sclera causes a marked fall. If "scleral" pressure is applied after "corneal" no such fall occurs and the author attributes this to a closure of the anterior angle caused by negative pressure acting at the limbus. In "scleral" pressure the angle probably remains open and free drainage is maintained.

\section{R. CAMPBELI.}

(3) Lindahl, J. (Osterund).-Two cases of transient myopia. (Zwei Falle von transitorischer Myopia). Acta Ophthal., Vol. XVI, p. 344, 1938.

(3) Lindahl reports two patients in whom myopia of a considerable degree had developed during the course of acute disease and disappeared rapidly. One patient was a man, aged 20 years, suffering from acute nephritis with mild oedema. At the height of the disease his refraction was R. -8, L. -9 . On the subsidence of the nephritis after twelve days the patient became emmetropic. The second case concerns a woman, aged 39 years, suffering from acute polyarthritis. She was given massive doses of salicylates. Six days after inception of salicylate treatment she showed $5 \mathrm{D}$. of myopia and four days after cessation she was emmetropic. The author stresses the heavy perspiration that this patient underwent and discusses the possibility of the myopia being due to changes in the sodium chloride concentration of the body fluids, as it is held to be in the transient myopia in diabetes.

ARNOLD SORSBY.

(4) Lodberg, C. V. (Viborn).-Congenital absence of abduction. (Absence congenitale de l'abduction). Acta Ophthal., Vol. XV, p. 247, 1937.

(4) Lodberg reports seven cases of congenital absence of abduction and gives an exhaustive survey of the literature on the 
subject, together with a detailed analysis of the symptoms. He stresses the following ten aspects:-

(1) absence of abduction in one or both eyes ;

(2) association with some limitation of adduction ;

(3) retraction of globe is present in 50 per cent. to 70 per cent.; when present this is a characteristic feature; in some cases there is a difference of $10 \mathrm{~mm}$.;

(4) narrowing of palpebral fissure with sinking in of the upper lid;

(5) elevation (sometimes depression) of globe on adduction;

(6) enophthalmos (rare);

(7) protrusio bulbi with widening of fissure on abduction ;

(8) in two cases there was a difference in the degree of movement when the patient was examined for each eye separately and binocularly;

(9) torticollis ;

(10) disturbances of vertical movement.

The author found the ratio of affected women to men to be $6: 4$; the left eye was involved in 75 per cent. of cases. As regards operative treatment he draws attention to the danger of perforating the sclera which in these cases is thin.

ARNOLD SORSBY.

(5) Kentgens, S. K. (Utrecht).-The relationship of pregnancy, disorders of dark adaptation and the vitamin A content of the blood. (Ueber den zusammenhang von schwangerschaft, störung der dunkeladaptation und dem Vitamin A-gehalt des

Blutes). Acta Ophthal., Vol. XVI, p. 332, 1938. 2......... G .

(5) Kentgens determined the vitamin A content of the blood by the colorimetric method of Wolff in nineteen patients in the last month of pregnancy. None of them were night-blind, though ten showed slightly lowered dark adaptation. Of these ten two had a normal and eight a lowered vitamin A content. Of the nine that had no disturbance in dark adaptation four showed a slight lowering of the vitamin A concentration. Twenty-four control cases showed that anomalies and dark adaptation were more frequent in pregnancy, but the presumption that these anomalies were dependent on a lowered vitamin A concentration could not be verified. Administration of vitamin A increased the sense of dark adaptation even in those cases where the vitamin A content was normal. There was, therefore, no quantitative relationship. The author concludes that disturbances in dark adaptation are not an early symptom of a vitamin A deficiency. These disturbances only come into play when the body has used up its storage of vitamin A.

ARNOLD SORSBY. 
(6) Aron, F. and Zeeman, W. P. C. (Amsterdam)-Atypical coloboma and spontaneous cyst of the iris. (Atypisches Kolobom und Spontane Iriscyste). Acta Ophthal., Vol. XVI, p. 380, 1938.

(6) Aron and Zeeman give the clinical and histological details of pseudoglioma observed in a girl aged six months. The family history was clear. Histologically the pseudoglioma was found to consist of a cyst of the iris situated between the stroma and the posterior leaf of the iris. The lens was displaced backwards. The wall of the cyst was covered with epithelium growing from the iris and ciliary body. There was a narrow fissure in the pigment layer of the iris. They hold that the cyst arose from an atypical coloboma of the iris and that it originated from the secondary optic vesicle, thus making it analogous to an orbital cyst in colobomatous eyes.

ARNOLD SORSBY.

(7) Licheri (Modena).-A rare case of exophthalmos. raro caso di esoftalmo). Arch. di Ottal., January, 1939.

(Un

(7) The patient in this case had suffered from migraine for many years. After an attack of the usual kind he suddenly experienced intense pain in the left orbit, with a sensation of heat and heaviness in the left eye; he noticed that the eye protruded. Shortly after he noted diplopia. On examination, the eye was seen to be protruded downwards and outwards; there was marked ptosis and limitation of movement in all directions. The skin was not red or oedematous. After some days an exploratory puncture was made and a quantity of turbid red-brown fluid was withdrawn; the eye went back into place, the ptosis disappeared and movements became normal. There seems no doubt that in this case there was a sudden haemorrhage into the orbital tissue. This usually depends on some general disease, weakening the vessels, but all disease of this nature seems absent here. Licheri imagines that the long-standing recurrent migraine was followed by some disturbance of the vascular system.

\section{HaRold Grimsdale.}

(8) Fontana (Modena).-The reaction of the ocular tissues towards bronze and aluminium. (Comportamento dei tessuti dell'occhio in presenza di scheggi metalliche endobulbari). Rass. Ital. d'Ocull., Nov.-Dec., 1938.

(8) Though the behaviour of the eye to copper is well known, not much is known of the reaction to bronze and still less of that to aluminium. Fontana has made experiments on rabbits, putting fragments and filings of these metals into the anterior chamber of the eye and masses into the vitreous. He finds that the introduction 
of bronze is followed by serious reaction similar to that of copper; this might have been expected since bronze is an alloy of copper and tin. Aluminium, on the other hand, is well borne and gives rise to no important disturbance.

HAROLD GRIMSDALE.

(9) Bertoldi (Turin).-A case of heterochromia iridis complicated by cyclitis and cataract. (Aproposito di un case di eterocromia dell'iride complicato da ciclite e cataratta). Rass. Ital. d'Ottal., Nov.-Dec., 1938.

(9) The patient, the subject of this note, has always found his left eye the better until recently; the right had a small paracentral macula of the cornea. The pupil and the palpebral fissure were slightly smaller than on the left side. The left eye showed many points of fine K.P.; and the left lens showed commencing cataract. The general examination revealed early tuberculosis. Bertoldi calls attention to certain points in the condition of the eye; there was slight enlargement of the pupil and of the palpebral fissure; the latter symptom increased after the instillation of cocaine. It seems probable that this showed increased action of the sympathetic. The low intra-ocular tension may have been due also to this.

\section{HAROLD GRIMSDALE.}

(10) Antoniotti (Turin). - The pupil in appendicitis. Il comportamento della pupilla negli ammalati di appendicite). Rass. Ital. d'Ottal., Nov.-Dec., 1938.

(10) It is never easy to diagnose chronic appendicitis with certainty. Any symptom which helps in this, is therefore very important. It has been stated that the right pupil generally is larger than the left in these patients. Antoniotti gives details of the pupils in 100 cases. He finds that in low light the right pupil is definitely the larger in 50 cases; he finds, further, that a weak solution of cocaine, 0.25 per cent., produced mydriasis, greater in the right eye; pilocarpine in solution 1 in 3,500 produced constriction of the pupils but the left was more constricted than the right. The cases seen, included acute appendicitis; 63 were chronic. Fifty of these showed the symptom, nearly 80 per cent. The mechanism of the reaction seems to be connected with the very rich nervous plexus over the appendix, which is irritated by any inflammatory process.

HAROLD GRIMSDALE. 


\section{II.-MEDICAL}

(1) Stallard, H. B. and Tait, C. B. V. (London). - Boeck's sarcoidosis. The Lancet, February 25, 1939.

(1) Stallard and Tait record a case of Boeck's sarcoidosis in a female patient aged 44 years. Signs showed themselves first in 1932 when a painless lump was noted in the right breast. Glands were present in the axilla of the same side and in the anterior and posterior triangles of the neck on the opposite side. Later in the year the growth in the breast and one of the glands in the posterior triangle were excised and showed the structure of sarcoid tissue.

In 1933 the patient was under treatment for irido-cyclitis of both eyes. A year later chronic uveitis, secondary cataract and a lowered intra-ocular pressure were noted, together with bilateral effusion into the knee joints. In early 1935 vision was reduced to perception of light; the irido-cyclitis was of the plastic variety and iris bombe was present in the right eye. The intra-ocular pressure was now raised on both sides. A left-sided iridectomy was performed but the coloboma gradually became occluded by fresh exudate.

Radiograms suggested healed sarcoidosis lesions in the right lung, but other investigations were negative.

Early in 1936 the left eye was soft and atrophic. There was keratitis in the right eye with ring staining and vascularisation of the cornea. The patient now had the classical features of myxoedema.

At the present time the left eye is shrunken and blind; in the right eye the tension is low and projection of light is inaccurate.

The paper is illustrated with photos of the present general condition together with microphotographs of tissue from the breast and axillary gland.

R. R. J.

(2) Sorsby, Arnold, Avery, Harold and Cockayne, E. A.-Obesity, hypogenitalism, mental retardation, polydactyly and retinal pigmentation. The Laurence-Moon-Biedl syndrome. Quarterly Jl. of Med., New Series, Vol. VIII, No. 29, January, 1939.

(2) Sorsby, Avery and Cockayne here present a paper which is complementary to that in the same journal by Cockayne, Krestin and Sorsby, which was noticed in our pages, Vol. XIX, p. 530. The previous paper analysed 101 cases from the literature up to 1935. The present report is on two families and includes an analysis of the many articles that have appeared in the past four years.

The two new familial groups reported in this paper are Jewish, in both cases the parents are first cousins and are normal. 
In the "G." family there were five pregnancies which went to full term, the children all being boys. The eldest is alive and normal. The second died, aged 23 years, from pneumonia. $\mathrm{He}$ was an inmate of a mental hospital and showed all the typical features of the syndrome. The next two boys died aged 10 years and $4 \frac{1}{2}$ years respectively. No definite facts were forthcoming about them. The youngest boy is now 17 years old, obese, mentally deficient and certified blind. Extra digits were removed from the hands in infancy. There is fleshy syndactyly in both feet; the left foot shows fusion of the 4th and 5th digits and in both feet there is fusion of the proximal parts of the second and third toes. Radiography shows no bony abnormality of hands or feet. The fundi show atypical retinitis pigmentosa with optic atrophy and gross pigmentation. The testes are undescended, the penis small and there is marked flat foot.

In the "M." family there were eleven pregnancies, two ending in miscarriage; of the living children only one was a boy. The eldest child died at three weeks. The youngest daughter and the boy, her immediate senior, are the only members affected.

The boy is 21 years old. When eight years old he was under the care of Mr. R. C. Davenport and was at that time a very obese child. For the past four years he has been distinctly lean. $\mathrm{He}$ is mentally defective and unemployable. There is no distinct hypogenitalism and no skeletal abnormalities apart from scoliosis: small fleshy excrescences are present on the ulnar aspect of each hand. There is marked nystagmus with much retinal atrophy with narrow arteries; pigmentary changes are absent, though the maculae suggest dystrophic changes. The girl is 19 years of age, stout but not grossly obese. She is defective and unemployable. Her fundi show the same changes as those of her brother; there is an extra finger on the ulnar side of the right hand. Menstruation appears to be normal.

These cases were shown at the Royal Society of Medicine, Section of Ophthalmology, in December, 1936, by Avery and Sorsby.

The rest of the present paper gives a review of recent literature, the components of the syndrome, post-mortem findings in three cases and a discussion. Case reports show the frequent occurrence of one or more components of the syndrome in the ascendants of patients showing the full syndrome. "No case of the inheritance of the full syndrome is known, though cases are reported indicating that patients exhibiting the syndrome are not sterile."

The condition is not confined to the Caucasian race. Available post-mortem records have not shown any characteristic lesions. Attention is here drawn to a series of allied conditions. "It is suggested that the syndrome is determined by two recessive genes 
in the same chromosome, or that it is dependent on some chromosome error such as dislocation or translocation."

Two pages of bibliography complete a paper, reported with the thoroughness we are accustomed to in the authors, which is a model of what a paper should be.

R. R. J.

(3) Valerio (Milan).-A rare case of Gunn's phenomenon. Su di un caso raro di fenomeno di Marcus Gunn). Riv. Oto.-Neuro. Oftal., December, 1938.

(3) The case recorded by Valerio is unusual in that the condition either began or was noticed to be more marked at the age of 18 years. There are a few cases in which the phenomenon is said to have been acquired, but for the most part, they have shown as in this case, a slight ptosis which increased. The chief interest in the paper is the discussion on the recent theories concerning the nature of the phenomenon. The first step, the author says, in the explanation was made by Grant, who noted that after instilling homatropine into both eyes in a case of this kind, the associated movement ceased. It is interesting to note that Gunn in his first case, used homatropine to both eyes and records a variation in the size of the pupils, but it is certain that no change in the movement could escape so careful an observer. Grant, having seen that elevation of the upper lid followed only on movement of the jaw to the left, thought that by abolishing this movement, he might benefit the patient, and determined to divide the motor branch of the fifth nerve. This he did with satisfaction to the patient. Lewy and Groff have investigated the phenomenon; they conclude that it is a form of pseudomotor movement, of the type of Heidenhain and Sherringham. They find that after dividing intra-cranially the oculo-motor nerve in a cat, an injection of acetyl choline was followed by great dilatation of the palpebral fissure of the same side; a similar action follows the injection of nicotine; stimulation by faradic electricity of the peripheral stump of the first branch of the trigeminal produced a similar reaction.

Lewy, later, stimulating the anterior end of the mesencephalic nucleus of the fifth nerve, after the division of the oculo-motor, obtained elevation of the upper lid. The nucleus seemed therefore to have an important part in the production of this phenomenon.

In the author's case, he wished to divide the motor branch of the fifth nerve but the patient refused; he eventually fixed the upper lid to the scleral insertion of the superior rectus; this from the patient's point of view, was entirely successful, the associated movement and the ptosis being less obvious.

HAROLD GRIMSDALE. 
(4) Schutzbach, M. (Halle).-A case of severe malformation involving especially the skull and face. (Ueber einen Fall von schwerer Missbildung, insbesondere des Schädels und des Gesichtsskeletts). Zeitschr. f. Augenheilk., Vol. XCIV, p. $131,1938$.

(4) Schutzbach reports a case showing some of the features of the Crouzon syndrome. The orbits were small and the eyes were not covered by the eyelids. The cornea was opaque and ultimately perforated. The child died at the age of five months. The family history showed the presence of the following affections:polydactyly, endothelial dystrophy, mental deficiency, cretinism and parenchymatous keratitis.

\section{ARNOLD SORSBY.}

(5) Böck, J. (Vienna).-Clinical and anatomical aspects of angeoid streaks. (Zur Klinik und Anatomie der gefäkähnlichen Streifen im Augenhintergrund). Zeitschr.f. Augenheilk., Vol. XCV, p. 1, 1938.

(5) Böck gives a detailed account of seven cases of angeoid streaks with pseudoxanthoma elasticum, together with an exhaustive review of the literature on the subject. Of special interest is the post-mortem report of one of the patients who died at the age of 44 years from vascular hypertension. Extensive changes were found in the elastic tissue of the aorta, the bigger systemic vessels and the choroidal vessels. The author concludes that the appearance of angeoid streaks is due to ruptures in the elastic membrane of Bruch - a condition he demonstrates histologically-and holds that in addition to the skin and eye changes there must now be added a third feature: degeneration of elastic tissues throughout the body. He suggests the name of elastosis dystrophica for this syndrome.

ARNOLD SORSBY.

(6) Freusberg, O. (Hamburg-Eppendorf).-Semi-homonymous papilloedema in partial optic atrophy due to a unilateral tract lesion. (Halbteilige homonyme Stauungspapille bei partialler Optikus atrophie nach ein-seitiger Traktuslasion). Klin. Monatsbl. f. Augenheilk., Vol. CI, p. 494, 1938.

(6) Freusberg gives the full history of a malignant glioma in the right frontal-parietal region which involved the optic tract and lateral geniculate body. Before operation there was right-sided papilloedema, and later slight optic atrophy in both eyes and left homonymous hemianopia-a condition which persisted for several years. In the terminal stages papilloedema again developed on the nasal side of the right disc-a change which is rarely seen. A full histological investigation of the brain showed the exact site of the affected tracts, while the optic nerve showed that only the functioning fibres were swollen, while the atrophied fibres on the temporal side did not take part in the papilloedema.

D. R. Campbell. 


\section{III.-THERAPEUTICS}

(1) Douthwaite, A. H. (London).-Recent developments in modern chemotherapy. The Practitioner, June, 1939, pp. 729736.

(1) This article is of value in clearing up any natural confusion in the nomenclature of certain drugs used in chemotherapy.

The term sulphonamide is a generic one and embraces all the drugs mentioned subsequently. The name sulphanilamide, on the other hand, denotes one substance, and one substance only, no matter what other titles it may bear; these trade titles are prontosil album, sulphonamide-P, consulanyde, prontylin and streptocide. It is p-amido-benzene-sulphonamide.

The most remarkable of the sulphonamides in respect of therapeutic activity is M and B 693 which is sulphanilyl-amino-pyridine which is especially efficacious against the pneumococcus and the gonococcus.

Proseptasine and soluseptasine are benzyl derivatives of sulphanilamide.

Other sulphonamides are prontosil rubrum, prontosil soluble, rubiazol and uleron.

Choice of drug. Sulphanilamide and M and B 693 are equally valuable for $\beta$-haemolytic streptococci; but in pneumonia and gonococcal infections the latter is to be preferred.

Dosage. It should be borne in mind constantly that the sulphonamides if they are to do good, will do so in a few days. They are rapidly absorbed (they can be found in the eye of a dog within 15 minutes of injection) and rapidly excreted, so the doses should be spread as evenly as possible over the 24 hours. M and B 693 may be given in two gramme doses (that is four tablets) every four hours for three doses; then 1 gramme every four hours for two days; then 0.5 gramme every four hours for one day; and finally 0.5 gramme thrice daily for two or three days. This dosage of 24 or 27 grammes is considered sufficient for acute diseases such as pneumonia. When chemotherapy has been applied in chronic diseases such as trachoma the number of grammes given over a period of a fortnight has been about double this. Such treatment for trachoma is highly empirical. We believe that trachoma is a disease of virus origin, and there is as yet very little evidence that sulphonamide compounds have any effect on virus diseases.

Toxic effects. Mental depression and lassitude are usual. Pyrexia is sometimes caused. Vomiting is not infrequent, whether of central or of local origin is not certain. Nore serious are cyanosis, methaemoglobinuria, and reduction in the number of polymorphonuclear leucocytes. In severe cases of cyanosis blood transfusion is indicated. 
Incompatibles. The following articles should be prohibited during chemotherapy :-All purgatives (paraffin not being a purgative is permitted to combat constipation), eggs (because of high sulphur content which might lead to the production of sulphaemoglobin), and phenacetin.

Toxic effects may be minimized by powdering the tablets and adding an equal quantity of sodium bicarbonate, or as the author suggests giving five minims of tincture of opium half-an-hour before each dose.

Conclusion. In conclusion the author gives a warning against the employment of any of these drugs as a "shot in the dark" for cryptic fever, or for the treatment of every case of sore throat, coryza, influenza and a host of other diseases. The danger of granulocytopenia, though not great, is nevertheless present, and only justifiably incurred in the face of greater and commoner hazards. There is no evidence that the sulphonamides influence the course of the common cold, influenza, or the typhoid group of infections except by increasing prostration and delaying recovery.

\section{A. F. MacCallan.}

(2) Marshall, Jr., E. K. (Johns Hopkins University).-Bacterial Chemotherapy, the pharmacology of sulphanilamide. Physiological Reviews, Vol. XIX, No. 2, 1939.

(2) The idea of developing specific chemical substances for the treatment of bacterial infections is as old as bacteriology itself. In 1881 Koch failed to cure anthrax with mercuric salts, and he and others found their experiments discouraging. However, in 1904 with Ehrlich's success with protozoan infections the search for drugs of chemotherapeutic value began again, but it has been only in the last few years that by haphazard trial and error that the value of the sulphonamide group of drugs was discovered. In 1908 Gelmo described the preparation of sulphanilamide in a purely scientific paper. By the substitution of various molecules he discovered different compounds, including dyes. In 1932 Domagk using a compound patented for dyeing cured streptococcal infections in mice; this was sold as prontosil.

In a study of the pharmacology of any therapeutic agent three lines of investigation are important: namely, the effect of the drug on the infecting organism in vivo in animals, the effect of the drug on the infecting organism in vitro under various conditions, and the effect of the drug on the host.

An interesting and important observation from the standpoint of the mechanism of action of these drugs is the fact that treated mice may die from streptococcal septicaemia a long time after treatment has ceased and without showing any symptoms in the interval. 
In the virus diseases studied sulphanilamide as well as prontosil and prontosil soluble have in the main given completely negative results. However, it has been shown by MacCallan and Findlay (Lancet, Vol. II, p. 136, 1938) that the treatment of mice infected intracerebrally with the virus of lymphogranuloma inguinale by sulphanilamide and by a glucose derivative of 4:41-diaminodiphenylsulphone gives these compounds the power of protecting a considerable percentage of mice against active strains of the virus.

The drug diffuses readily to all tissues and fluids of the body, which is one of the factors which make the substance a successful chemotherapeutic agent.

So far all these newer compounds which have been shown to be active against bacterial infections contain sulphur. It has been demonstrated, however, that the sulphonamide group is not necessary for activity.

It seems that the balance of evidence indicates that sulphanilamide affects the invading organism in the sense of producing a bacteriostatic or bactericidal action which in many cases is not sufficient to effect sterilization without the co-operation of the defensive reaction of the host.

\section{A. F. MacCallan.}

(3) Wheeler, J. N. (New York).-Spastic entropion correction by orbicularis transplantation. Trans. Amer. Ophthal. Soc., Vol. XXXVI, p. 157, 1938.

(3) Wheeler reviews the operative procedure for the correction of spastic entropion and comments on the recurrence of this disorder in spite of surgical attention. He describes two operations which have the advantage of producing a permanent effect and of affording support to the lower lid. In neither operation is any skin or muscle sacrificed.

(i) A skin incision is made $6 \mathrm{~mm}$. below the lower lid margin beginning to the nasal side of the centre of the lower lid and carried in a line parallel with the lower lid margin outwards to a point $1 \mathrm{~cm}$. beyond the orbital margin. The skin is dissected from the orbicularis muscle. Over the lower border of the tarsal plate a strip of orbicularis muscle $4 \mathrm{~mm}$. wide is dissected up and divided at the orbital margin on the temporal side, the nasal end is left attached. An incision is then made in the orbicularis muscle and carried from the temporal extremity of the orbicularis strip outwards and slightly upwards to the limit of the skin incision and down to the periosteum covering the malar bone, which is then exposed by retracting the cut edges of the orbicularis muscles. The strip of orbicularis muscle is then carried outwards and slightly upwards and made taut over the malar bone, of which it is sutured to the periosteum with 000 catgut and then wound closed with interrupted sutures. 
(ii) An alternative to the above operation is as follows: A skin incision is made $5 \mathrm{~mm}$. below and parallel with the lower lid margin for almost its entire length. The skin flaps are dissected to expose the orbicularis muscle. A strip of this muscle $4 \mathrm{~mm}$. wide just below the lower border of the tarsus is dissected up and divided in the centre.

A 000 catgut suture is passed through the tarso-orbital fascia $2 \mathrm{~mm}$. below the lower margin of the tarsus and is then carried in turn through each flap of the orbicularis strip so as to produce an overlap 4 or $5 \mathrm{~mm}$. This suture is then tied and the overlap made secure by two additional sutures.

There is a tendency for over-correction to occur from this operation but the author considers that a 4 or $5 \mathrm{~mm}$. overlap affords the most exact adjustment.

H. B. Stallard.

(4) Rosengren, B. (Gotenburg). - The treatment of retinal detachment by diathermy and injection of air into the vitreous. (Ueber die Behandlung der netzhautablösung mittelst Diathermie und Luftinjektion in den Glaskorper). Acta Ophthal., Vol. XVI, p. 3, 1938.

(4) Rosengren after discussing several aspects of diathermy treatment in detachment, holds that contact of the retina with its bed is essential and advocates the method first suggested by Arruga, viz., injection of air into the vitreous by means of a syringe introduced behind the ciliary body. The injection should be controlled ophthalmoscopically. In such cases where the detachment is situated in a mechanically unfavourable place, the eye may have to be pulled down by means of a suture passed through the superior rectus and through the lower lid, so that the new position enables the air to exercise its pressure most effectively. These sutures can be removed after seven to ten days. He reports fourteen successes in a series of eighteen cases treated by this method.

\section{ARNOLD SORSBY.}

(5) Hausmann, G. (Vienna).-Report on short wave therapy in the First University Eye Clinic in Vienna. (Bericht ueber Kurzwellentherapie an der I. Universitäts-Augenklinik in Wien). Zeitschr. f. Augenheilk., Vol. XCIII, p. 213, 1937.

(5) Hausmann reports on the results of short-wave therapy in thirty-one cases, consisting of five showing post-operative infection, nine perforating injuries, seven chronic uveitis, six serpigenous ulcer, two herpes of the cornea and two dacryocystitis. Three of the five cases of post-operative infection, two of the perforating injuries and the four cases of herpes and dacryocystitis did well. There was no damage done in any of the others. The wave length used was three metres.

ARNOLD SORSBY. 
(6) Werdenberk, Ed. (Davos).-The fundamentals of knowledge and therapy of ocular tuberculosis. (Grundsatzlicher zur Kenntnis zur Therapie des Augentuberkulose). Klin. Monatsbl. f. Augenheilk., Vol. CI, p. 641, 1938.

(6) Werdenberk gives statistical results of twenty years' experience of ocular tuberculosis. He recognises three types of the disease which are well exemplified in iritis, viz., exudative, productive (nodular), and fibrous. The first is usually associated with a lack of immunity, while in the later types immunity is usually well-established. Ocular tuberculosis usually negatives the presence of thoracic infection-the latter being present in only 30 per cent. of cases. The author considers that infection spreads by the lymphatics, and draws attention to the analogous pathological changes which can occur in the lung and in the iris, e.g., miliary deposits, pus formation, and adhesions. He considers tubercular dermal tests are of no real value, and that diagnosis must rest on clinical appearance and the exclusion of other forms of infection.

General treatment is most important and high altitude has a most beneficial effect. Tuberculin treatment is only effective in about 10 per cent. of cases. The author details those forms of treatment which are harmful.

D. R. CAMPBEll.

(7) Tsopelas, B. (Berlin). - The treatment of 3 cases of occlusion of the central retinal artery with Eupaverin (Merck). (Ueber die Behandhung von 3 Fallen von Verschluss der Arteria centralis Retinae mit Eupaverin Merck). Klin. Monatsbl. $f$. Augenheilk., Vol. CI, p. 830, 1938.

(7) Tsopelas describes three cases of non-embolic occlusion of the central retinal artery, two of which showed a certain amount of recovery of vision and visual field after injections of eupaverin. This was given intravenously in doses of 2 c.c. for several days, amounting to a total of 20 c.c.

D. R. CAMPBELL.

(8) Borioni (Rome).-Folliculin in the treatment of gonococcal conjunctivitis. (La follicolina nella terapia delle congiuntiviti gonococciche). Boll. d'Ocul., September, 1938.

(8) Borioni has compared this treatment with that of argyrol; he used it in one eye of bilateral cases, keeping the other as control under argyrol; he finds the results similar. He gave folliculin also by the mouth, so that perhaps the comparison is not quite fair. The cost of argyrol is much less.

HAROLD GRIMSDALE. 